\title{
Once daily injection of exendin-4 to diabetic mice achieves long-term beneficial effects on blood glucose concentrations
}

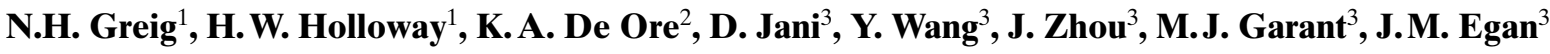 \\ ${ }^{1}$ Drug Design and Development Section, National Institute on Aging, NIH, Baltimore, Maryland, USA \\ ${ }^{2}$ Diabetes Section, Gerontology Research Center, National Institute on Aging, NIH, Baltimore, Maryland, USA \\ ${ }^{3}$ Howard University Medical School, Washington, District of Colombia, USA
}

\begin{abstract}
Summary Glucagon-like peptide- 1 is the main hormonal mediator of the enteroinsular axis. Recently, it has additionally received considerable attention as a possible new treatment for Type II (non-insulin-dependent) diabetes mellitus. Its major disadvantage is that its duration of action is too short to achieve good 24-h metabolic control. Exendin-4, which is produced in the salivary glands of Gila monster lizards, is structurally similar to glucagon-like peptide- 1 and shares several useful biological properties with glucagon-like peptide-1. It binds the glucagon-like peptide- 1 receptor, stimulates insulin release and increases the cAMP production in beta cells. We report that exendin-4 is a more potent insulinotropic agent when given intravenously to rats than is glucagonlike peptide-1 $\left(\mathrm{ED}_{50} 0.19 \mathrm{nmol} / \mathrm{kg}\right.$ for glucagon-like peptide-1 vs $0.0143 \mathrm{nmol} / \mathrm{kg}$ for exendin-4) and causes a greater elevation in cAMP concentrations in iso-
\end{abstract}

lated islets. Of even greater interest we found that when given intraperitoneally only once daily to diabetic mice it had a prolonged effect of lowering blood glucose. After 1 week of treatment blood glucoses were $5.0 \pm 2.6 \mathrm{mmol} / \mathrm{l}$ compared to diabetic concentrations of $13.2 \pm 2.8 \mathrm{mmol} / \mathrm{l}$. After 13 weeks of daily treatment $\mathrm{HbA}_{1 \mathrm{c}}$ was $8.8 \pm 0.4 \%$ in non-treated diabetic animals compared with $4.7 \pm 0.25 \%$ in treated diabetic animals. Blood glucoses also were lower $(p<0.005)$ and insulin concentrations higher $(p<0.02)$ in the treated animals. Exendin- 4 could therefore be preferable to glucagon-like peptide- 1 as a long-term treatment of Type II diabetes. [Diabetologia (1999) 42: 45-50]

Keywords Exendin-4, glucose, GLP-1, db/db mice, Wistar rats.
In recent years several new agents have become available to treat Type II (non-insulin-dependent) diabetes mellitus within the United States. These include metformin, acarbose and troglitazone as the latest. However, the drop in $\mathrm{HbA}_{1 \mathrm{c}}$ obtained by these newer agents is less than adequate [1] and they fail to normalize concentrations of glycaemia. In conjunction with this, Type II diabetes is a progressive dis-

Received: 30 March 1998 and in final revised form: 5 October 1998

Corresponding author: J.M. Egan, M.D., Diabetes Section, Box \#23, GRC/NIA/NIH, 5600 Nathan Shock Drive, Baltimore MD 21224, USA

Abbreviations: GLP-1, Glucagon-like peptide-1; db/db mice, C57BLKS/J-Lepr ${ }^{\mathrm{db}} /$ Lepr $^{\mathrm{db}}$ mice. ease because beta cell function continues to deteriorate despite on-going treatment with any currently available agent [2]. Glucagon-like peptide-1 (GLP1) is another potential therapeutic agent that has been shown to lower blood glucose in Type II diabetes [3]. It causes euglycaemia by increasing insulin release and synthesis, inhibiting glucagon release and decreasing gastric emptying [4-8]. Unfortunately, GLP-1 will probably have limitations as a therapeutic agent because of its short biological half-life [8], even when given by a bolus subcutaneously [9]. It could, however, be infused continuously by using a constant subcutaneous delivery system such as is currently successfully undertaken with insulin for tight control of Type I (insulin-dependent) diabetes mellitus. Be that as it may, this would introduce added complexity and expense to its practical use. 
Exendin- 4 is a peptide produced in the salivary glands of the Gila monster lizard. Although it is the product of a uniquely non-mammalian gene and appears to be expressed only in the salivary gland [10], it shares a $52 \%$ sequence homology with GLP-1 and in mammals it interacts with the GLP-1 receptor [11, 12]. In this paper we report that in Wistar rats, bred in the National Institute of Aging (NIA), it was a far more effective insulinotropic agent than is GLP-1. We further report that exendin-4 leads to sustained improvement of diabetic control in a rodent model of Type II diabetes.

\section{Materials and methods}

Materials. Exendin-4 and GLP-1 were purchased from Bachem (King of Prussia, Pa., USA). Chemical reagents were from Sigma (St. Louis, Mo., USA), unless otherwise stated.

Animals. Wistar rats (4 months old) from the Wistar colony in the NIA (Baltimore, Md., USA) were used for the short-term experiments of the effects of exendin-4 and GLP-1 [13]. They had been maintained on standard laboratory chow and fed ad libitum. For the long-term experiments, $\mathrm{db} / \mathrm{db}$ mice $\left(\mathrm{C} 57 \mathrm{BLKS} / \mathrm{J}-\right.$ Lepr $^{\mathrm{db}} /$ Lepr $^{\mathrm{db}}$ ) lacking the leptin receptor and their non-diabetic littermates were purchased at 4 weeks of age from Jackson Laboratories (Bar Harbor, Mass., USA). They were housed, two per cage, and also fed ad libitum. The same mice were caged together for the duration of the study. Wistar rats were caged on wire and the bedding for the mice was a paper based product, "Carefresh" (Absorption Co., Bellingham, Wash., USA).

Protocols. Wistar rats were fasted overnight. After intraperitoneal (i.p.) anaesthesia with $50 \mathrm{mg} / \mathrm{kg}$ pentobarbital, a catheter was placed in the femoral artery for blood sampling. A bolus of either exendin- 4 or GLP-1 $(0.01,0.05,0.1,0.2,0.3,0.4$ $\mathrm{nmol} / \mathrm{kg}$ ) was given into the saphenous vein (i. v.) over $30 \mathrm{~s}$ to 6 animals per peptide concentration. Blood (taken at $-5,0,2$, $5,15,30,60,120$, and $180 \mathrm{~min})$ was drawn into heparinized tubes containing EDTA and aprotinin for insulin determination [13].

After 2 days of acclimatization to our facilities, whole blood glucose concentrations, taken from a retro-orbital sinus, were determined in the mice using a Glucometer Elite (Bayer, Elkhart, Ind., USA). We have 11 diabetic and 10 non-diabetic animals $24 \mathrm{nmol} / \mathrm{kg}$ exendin-4 i.p. daily thereafter (0700-0900 hours) and 10 diabetic and 10 non-diabetic animals $\mathrm{NaCl}$ i.p. This regimen was continued for 12-13 weeks. On day 8 , two of the non-diabetic mice (cage-mates) and on day 14 one of the diabetic mice died just after receiving exendin-4. Animals were weighed weekly. After 1 week of the regimen, blood samples were again taken from a retro-orbital sinus for determination of insulin and glucose concentrations. At the end of the regimen, fasting blood samples were obtained for these concentrations and whole blood containing EDTA was assayed for $\mathrm{HbA}_{1 \mathrm{c}}$ on the same day from the four groups.

In another group of mice we gave $24 \mathrm{nmol} / \mathrm{kg}$ exendin- 4 and $\mathrm{NaCl}$ i.p. daily to six diabetic and six non-diabetic animals for 8 days. We weighed them and their food intake daily to monitor for any short-term effects of exendin-4 on those variables.
cAMP determinations. Islets of Langerhans were harvested from Wistar rats [14] and batches of 25 islets were then incubated for $1 \mathrm{~h}$ at $37^{\circ} \mathrm{C}$ in a buffer containing (mmol/l) 140 $\mathrm{NaCl}, 5 \mathrm{KCl}, 1 \mathrm{NaPO}_{4} 1 \mathrm{MgSO}_{4}, 5$ glucose, $2 \mathrm{CaCl}_{2}, 20 \mathrm{~N}$-2-hydroxyethylpiperazine- $\mathrm{N}^{\prime}-2$ ethanesulphonic acid (HEPES), buffer (pH 7.4) and $0.1 \%$ bovine serum albumin. Following this, they were inculated in the same buffer for $1 \mathrm{~h}$ in the presence of GLP-1 (1 nmol/l) or exendin-4 ( $1 \mathrm{nmol} / \mathrm{l})$. Some batches of islets were then washed three times with ice-cold phosphate buffer saline and lysed with $1 \mathrm{ml}$ ice-cold $0.6 \mathrm{mmol} / \mathrm{l}$ perchloric acid. Other batches were washed three times in the buffer at $37^{\circ} \mathrm{C}$ to remove peptide, and left another $15 \mathrm{~min}$ before being washed three times in ice-cold phosphate buffer saline followed by lysis with the perchloric acid. The lysates $(950 \mu \mathrm{l})$ were then transferred to microcentrifuge tubes and cAMP was measured, as described previously [15] using a cAMP $\left[{ }^{3} \mathrm{H}\right]$ assay kit (Amersham, Arlington Heights, Ill., USA). Cellular protein was assayed using the Bradford method ( Bio-Rad, Richmond, Calif., USA) with bovine y-globulin as a standard.

Assays. Plasma glucose was measured by the glucose oxidase method [13]. Insulin was measured by RIA, as published previously [13-15]. We assayed $\mathrm{HbA}_{1 \mathrm{c}}$ with a Bio-Rad (Herculas, Calif., USA) DiaSTAT machine which uses low pressure cation exchange chromatography in conjunction with gradient elution to separate haemoglobin subtypes and variants from haemolysed blood. The separated haemoglobin fractions were monitored by means of absorption of light at 415 $\mathrm{nm}$.

Statistical methods. All results are given as means \pm SEM. Student's $t$ tests were based on the results of an $F$ test that assessed the equality of variance of the two means. If the variances were statistically significantly different then the $t$ test was based on unequal variances. For determination of the $\mathrm{ED}_{50}$, basal plasma insulin concentrations were subtracted and the remaining activity at each concentration was expressed as a per cent of the maximum activity (achieved by an excess of peptide). This then was transformed into a logit format where logit $=\ln (\%$ activity/[100- $\%$ activity $])$ and was plotted as a function of the log concentration of the compound.

\section{Results}

Acute effects of exendin-4 vs GLP-1 given i.v. to Wistar rats. Exendin-4 was a more effective insulinotropic agent than GLP-1 on several concentrations when given intravenously. Maximum insulin response in our Wistar rats was seen with $0.4 \mathrm{nmol} / \mathrm{kg}$ GLP-1 [8]. At this same exendin-4 concentration maximum insulin response was appproximately doubled compared with GLP-1 (Fig. 1). Insulin concentrations returned to fasting concentrations by $15 \mathrm{~min}$ with GLP-1 but with exendin-4 they actually went below fasting concentrations and had returned to baseline by $60 \mathrm{~min}$. Using the data from the plasma insulin concentrations in response to the various peptide concentrations we found that the $\mathrm{ED}_{50}$ values were 0.0143 compared with $0.19 \mathrm{nmol} / \mathrm{kg}$ for exendin-4 compared with GLP-1, respectively. 


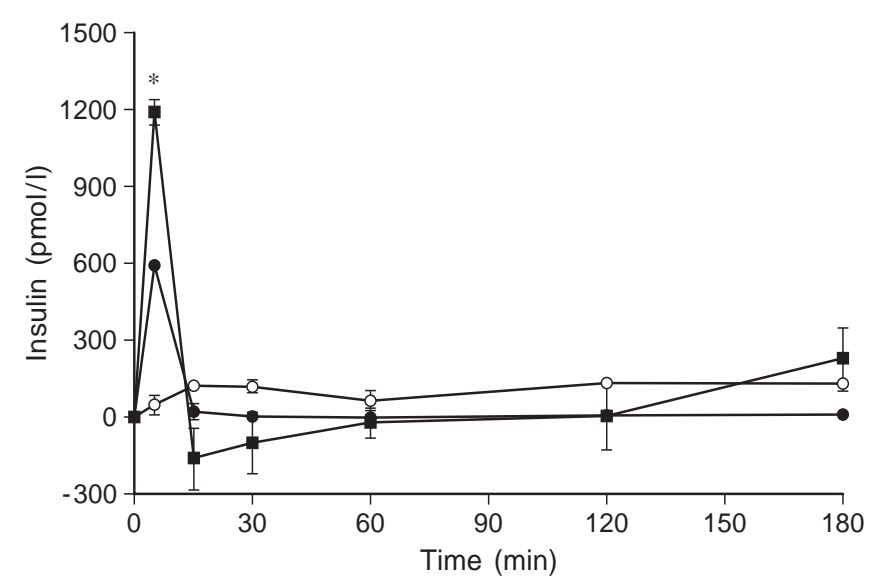

Fig.1. GLP-1 (0.4 nmol/kg), exendin-4 (0.4 nmol/kg) or $100 \mu \mathrm{l}$ $\mathrm{NaCl}$ were administered by intravenous boli to fasted, anaesthetised rats and samples taken at the times indicated. Values are expressed as means $\pm \operatorname{SEM}\left(n=6\right.$ per group, ${ }^{*} p<0.001$, exendin-4 vs GLP-1 injection). -ם- Exendin. 4; - - GLP-1; $-\bigcirc-\mathrm{NaCl}$

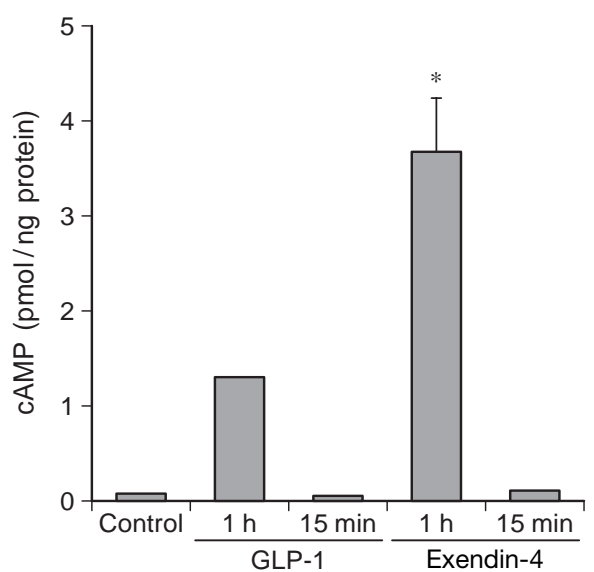

Fig. 2. Effects of GLP-1 (1 nmol/l) and exendin-4 (1 nmol/l) treatment on intracellular cAMP concentrations in islets of Langerhans. Values are expressed as means \pm SEM of four experiments, each done in triplicate, $* p<0.01$, exendin- 4 vs GLP-1 treatment for $1 \mathrm{~h}$, followed by a $15 \mathrm{~min}$ washout period

Effects of exendin-4 and GLP-1 on cAMP concentrations in isolated islets. Exendin-4 increased cAMP concentrations more in isolated islets than GLP-1 at equimolar concentrations. Glucagon-like peptide-1 increased cAMP in a concentration-dependent manner with a maximum cAMP response at $1 \mathrm{nmol} / \mathrm{l}$. At a similar concentration of exendin-4, cAMP concentrations were approximately threefold higher (Fig. 2) than with GLP-1. To elucidate whether or not exendin-4 or GLP-1 might bind and remain on the GLP-1 receptor and so maintain an increase in cAMP after removal of the peptides from the buffer solution we removed the peptide from some islet preparations by three washes with fresh buffer and then measured cAMP at $15 \mathrm{~min}$. For both peptides, cAMP concen-
Table 1. Effects of 1-week treatment with exendin-4 or $\mathrm{NaCl}$ in 5-week-old mice

\begin{tabular}{lcl}
\hline $\begin{array}{l}\text { Animal groups } \\
n=5-11 \text { per group }\end{array}$ & $\begin{array}{l}\text { Fasting blood } \\
\text { glucose }(\mathrm{mmol} / \mathrm{l})\end{array}$ & $\begin{array}{l}\text { Fasting serum } \\
\text { insulin concentra- } \\
\text { tions (pmol/l) }\end{array}$ \\
\hline Diabetic $+\mathrm{NaCl}$ & $13.2 \pm 2.8$ & $1,104 \pm 620$ \\
Diabetic + exendin-4 & $5.0 \pm 2.6$ & $8,112 \pm 563^{\mathrm{b}}$ \\
Non-diabetic $+\mathrm{NaCl}$ & $7.5 \pm 0.3$ & - \\
Non-diabetic + exendin-4 & $3.9 \pm 1.4$ & -
\end{tabular}

Results are expressed as means \pm SEM. ${ }^{\mathrm{a}} p<0.05,{ }^{\mathrm{b}} p<0.002$. Exendin-4 $(24 \mathrm{nmol} / \mathrm{kg})$ and $\mathrm{NaCl}$ were given intraperitoneally daily

trations had returned to baseline within 15 min with no statistical difference between the basal concentrations in each treatment group.

Effects of long-term treatment with exendin-4 in mice. At the initiation of the daily i.p. exendin-4 regimen in the mice, fasting blood glucose was lower in the non-diabetic mice at $8.06 \pm 2.8 \mathrm{mmol} / \mathrm{l}$ compared with $12.9 \pm 2.1 \mathrm{mmol} / \mathrm{l}$ in the diabetic mice $(p<0.01)$. After 1 week of treatment, the fasting glucose level in the exendin-4-treated non-diabetic mice was $3.9 \pm 1.4 \mathrm{mmol} / \mathrm{l}$ and was lower than in the $\mathrm{NaCl}$ treated non-diabetic animals, $7.5 \pm 0.3 \mathrm{mmol} / \mathrm{l}$ $(p<0.05)$. The diabetic animals had a high response to exendin-4. Glucose concentrations were $5.0 \pm 2.6 \mathrm{mmol} / 1$ in the exendin-4-treated animals compared with $13.2 \pm 2.8 \mathrm{mmol} / \mathrm{l}(p<0.002)$ in the $\mathrm{NaCl}$-treated animals (Table 1 ). There was no significant difference in blood glucose between the exendin-4-treated diabetic and non-diabetic animals. In addition we measured fasting insulin concentrations in the diabetic animals that received $\mathrm{NaCl}$ or exendin-4. They were higher in the animals that received exendin-4 $(p<0.002)$.

We continued to treat the animals daily with exendin-4. As the bedding was a paper-based product which turned progressively darker with increased urination, it became clear that the cages containing the exendin-4-treated diabetic animals, although not totally dry, as were the non-diabetic cages, were always obviously drier $24 \mathrm{~h}$ after changing than were the cages of the NaCl-treated diabetic animals.

Based on the weekly weights there were no statistical differences between the exendin-4- and $\mathrm{NaCl}-$ treated non-diabetic animals (Fig.3). Neither were there any differences between the exendin-4- and $\mathrm{NaCl}$ - treated diabetic animals up until 11 weeks of treatment. The diabetic animals were clearly heavier than the non-diabetic animals. After 9 weeks, the weight of the non-diabetic animals reached a plateau weight while the diabetic animals continued to gain weight. At 11-13 weeks of treatment the $\mathrm{NaCl}$-treated diabetic animals began to lose weight while the exendin-4-treated animals maintained their weight. 


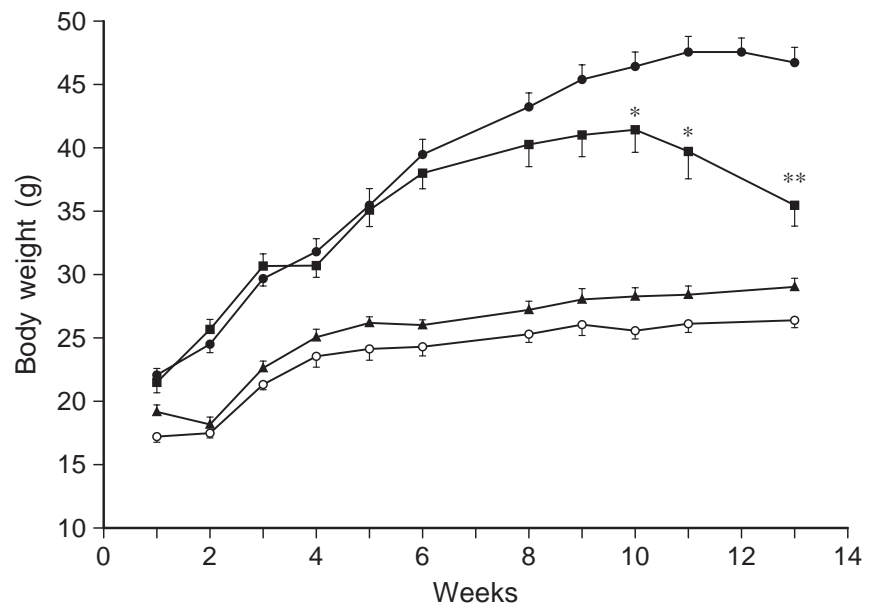

Fig.3. Weekly weights in the diabetic and non-diabetic mice given either exendin-4 $(24 \mathrm{nmol} / \mathrm{kg})$ or $\mathrm{NaCl}$ intraperitoneally daily for 12-13 weeks. Values are expressed as means \pm SEM, $* p<0.05, * * p<0.01, n=8-11$ per group, $\mathrm{NaCl}$ vs exendin-4 treated diabetic mice. - $\mathbf{-}$ - diabetic mice $\mathrm{NaCl}$; - - -diabetic mice exendin 4; - $\bigcirc$ - non-diabetic mice exendin 4 ; - $\mathbf{\Delta}$ - non-diabetic mice $\mathrm{NaCl}$

In the added group of animals that had daily weights and food intake monitored, daily injections of exendin- 4 caused a decrease in food intake in the non-diabetic animals for the first 3-4 days of treatment, which was reflected in a decrease in body weight by day 4 (Fig. 4), but these variables were not statistically different from $\mathrm{NaCl}$-treated animals by day 7 . In the diabetic animals exendin-4 decreased food intake also for the first 5-6 days, which was reflected in a decrease in body weight on days 5 and 6 . By day 7, however, body weights and food intake were not different from the $\mathrm{NaCl}$-treated animals.

We assayed the whole blood of the $\mathrm{NaCl}$ - and exendin-4-treated animals for $\mathrm{HbA}_{1 \mathrm{c}}$ determinations and measured plasma glucose and insulin concentrations after an overnight fast (Fig.5). It can be seen that all these variables were altered by the daily exendin- 4 treatment. The $\mathrm{HbA}_{1 \mathrm{c}}$ was $8.8 \pm 0.4 \%$ in the $\mathrm{NaCl}$-treated diabetic animals compared with $4.7 \pm 0.25 \%$ in the exendin-4-treated animals $(p<0.0001)$. It also was lower in the non-diabetic animals, $3.5 \pm 0.08 \%$ compared with $3.1 \pm 0.07 \%$ $(p=0.0002)$, for exendin-4-treated compared with $\mathrm{NaCl}$-treated, respectively. The $\mathrm{HbA}_{1 \mathrm{c}}$ was still clearly higher in the exendin-4-treated diabetic animals compared with non-diabetic animals $(p<0.0001)$. Glucose concentrations were lower $(15.5 \pm 1.7$ vs $28.7 \pm 3.3 \mathrm{mmol} / \mathrm{l}, p<0.005$, Fig. 5$)$ in the exendin-4- compared with $\mathrm{NaCl}$-treated diabetic animals though still higher than in non-diabetic $\mathrm{NaCl}$-treated animals $(p<0.001)$. Insulin concentrations were higher $(4,600 \pm 1,114$ vs $707.2 \pm 169.7$ $\mathrm{pmol} / 1, p<0.02)$ in the exendin-4- compared with $\mathrm{NaCl}$-treated diabetic animals (Fig. 5). The trends in
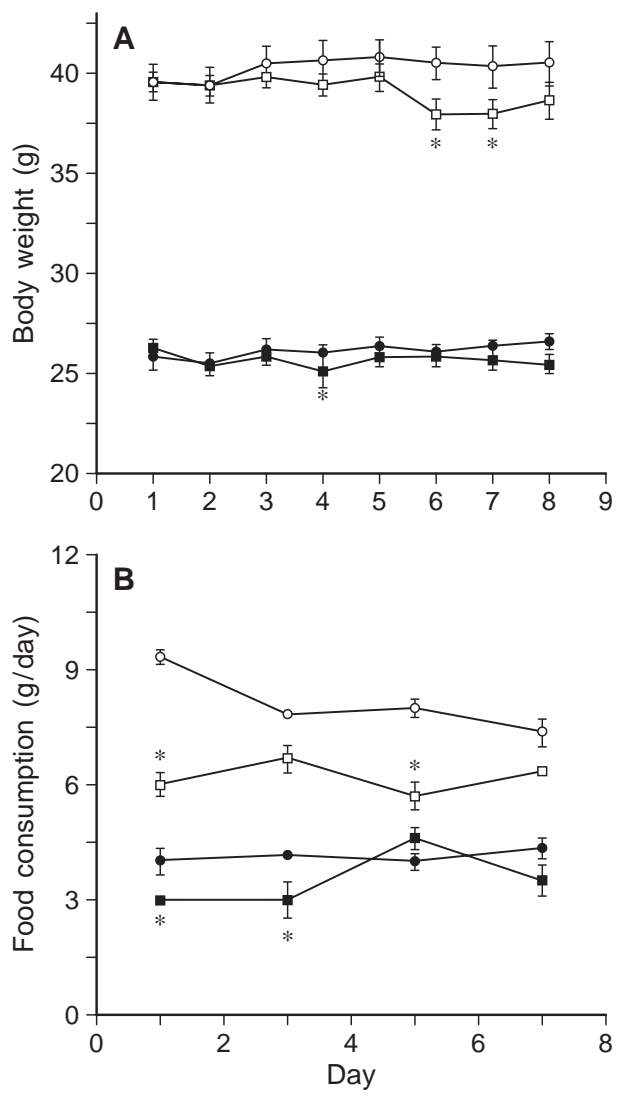

Fig. 4A, B. Daily weights (A) and food consumption $(\mathbf{B})$ in the diabetic and non-diabetic mice given either exendin-4 (24 $\mathrm{nmol} / \mathrm{kg}$ ) or $\mathrm{NaCl}$ intraperitoneally daily for 8 days. Values are expresssed as means $\pm \operatorname{SEM}(n=6$ per group, $* p<0.05)$. $-\square$ - diabetic mice exendin 4 ; - $\bigcirc$ - diabetic mice $\mathrm{NaCl} ;-\square$ - nondiabetic mice exendin 4 ; - - - non-diabetic mice $\mathrm{NaCl}$

glucose and insulin were the same in the non-diabetic animals with exendin-4 treatment, although not as dramatic (Fig. 5).

\section{Discussion}

Present knowledge of exendin- 4 suggests that it is an agonist of GLP-1 which acts on the known, cloned GLP-1 receptor to induce insulin release $[11,12,16]$. It is, however, clearly a far more effective insulinotropic agent than GLP-1. Not only were the beta cells of the pancreas much more sensitive, as judged by the lower $\mathrm{ED}_{50}$, but maximum insulin secretion increased in response to exendin-4. This increase in maximum secretion was probably due to a greater increase in cAMP concentrations in beta cells. Indeed, it has already been shown in an insulinoma cell line that exendin-4 causes a greater increase in intracellular cAMP than GLP-1 [11] and that in C57BLKS/JLepr $^{\mathrm{db}} /$ Lepr $^{\mathrm{db}}$ mice exendin- 4 is three orders of magnitude more potent than GLP-1 in lowering plasma glucose [17]. 

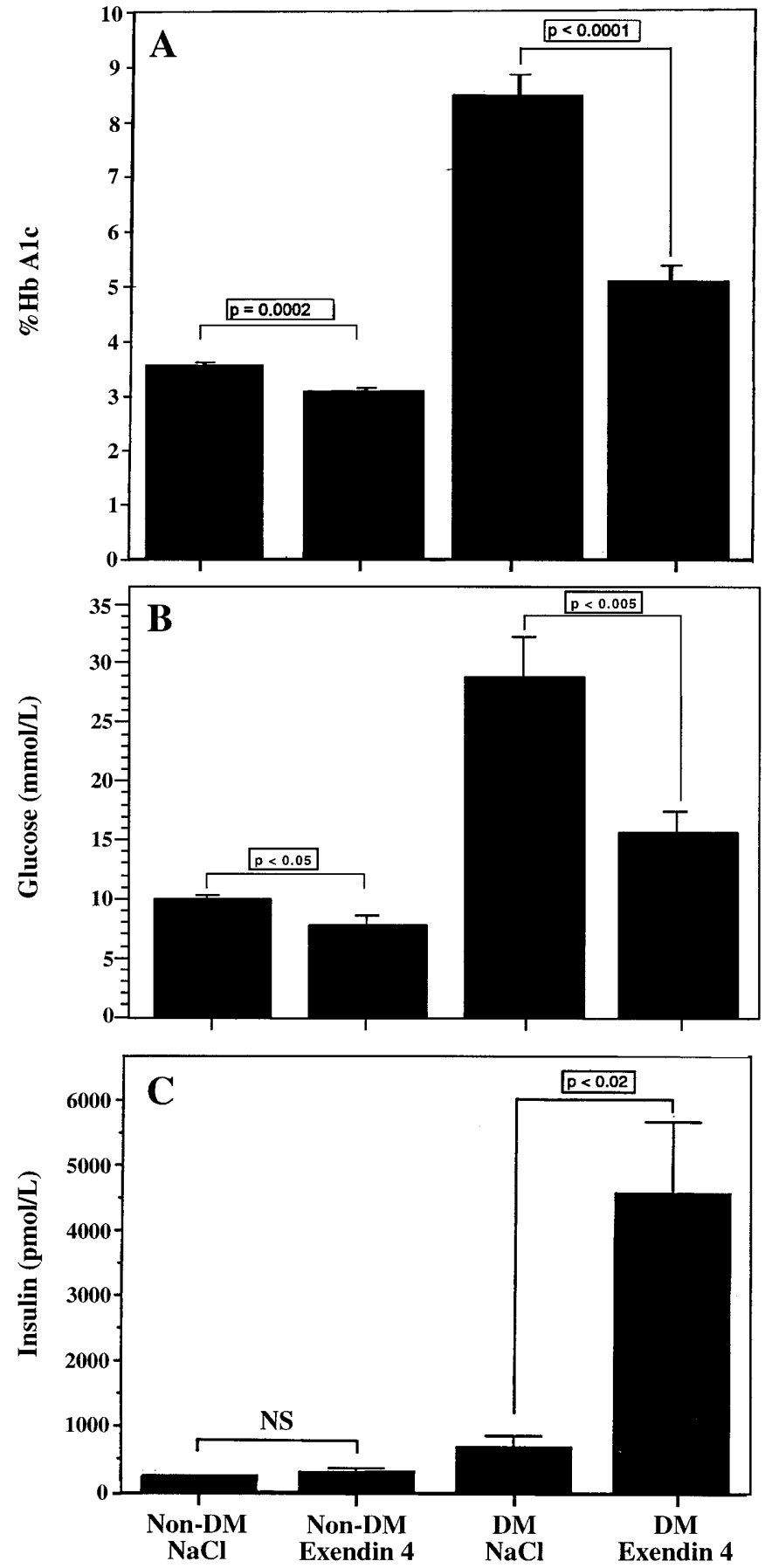

Fig. 5 A-C. Haemoglobin $\mathrm{A}_{1 \mathrm{c}}\left(\mathrm{Hb}_{1 \mathrm{c}}\right)(\mathbf{A})$, glucose $(\mathbf{B})$ and insulin $(\mathbf{C})$ concentrations after a $16-\mathrm{h}$ fast in the diabetic and non-diabetic mice given either exendin-4 (24 nmol/kg) or $\mathrm{NaCl}$ intraperitoneally daily for $12-13$ weeks. Values are expressed as means \pm SEM $(n=7-9$ per group). $* p=0.002$, ** $p<0.0001, * * * p<0.05,+p<0.005,+++p<0.02$. Nondiabetic apendin 4 is compared to non-diabetic $\mathrm{NaCl}$ and diabetic exendin- 4 is compared to diabetic $\mathrm{NaCl}$

At the end of 1 week of treatment with exendin-4, the fasting blood glucoses, as a result of just one injection a day, were lower than in those of the non-diabetic animals. This encouraged us to continue the injections long-term. Whereas over the entire course of the study i.p. exendin-4 did not keep blood glucose in the euglycaemic range, it much reduced, though did not prevent, some rise in $\mathrm{HbA}_{1 \mathrm{c}}$ in the diabetic animals. This effect was also seen in the non-diabetic animals that received exendin-4.

It is possible that as well as being insulinotropic, exendin-4 has an added effect of increasing glucose uptake in insulin-sensitive tissues, which might account for some of the dramatic drop in blood glucoses in the diabetic animals. Our present studies did not, however, address these issues. One other possible scenario is that the kinetics of subcutaneous and intraperitoneal compared with intravenous exendin-4 are very different. We do not yet have an antibody of sufficient quality to assay exendin-4 in blood. It is also possible that exendin- 4 had such a major beneficial effect in our diabetic mice because its treatment was begun early in the course of their diabetes and it therefore protected the beta cells of the pancreas from dysfunction due to increasing hyperglycaemia, i. e. it protected them from glucotoxicity.

We have given exendin-4 at a lower concentration $(1 \mathrm{nmol} / \mathrm{kg})$ i.p. for 1 week to diabetic mice. It proved just as effective at lowering blood glucose as the larger amount reported in this paper (data not shown).

We saw no untoward effects of daily exendin-4 injections on the behaviour of the mice. We observed that for the first 3-4 days of injection the weight of the animals and food intake dropped, but by the seventh day these variables returned to normal and were no different from the $\mathrm{NaCl}$-treated animals. As it has been proposed that GLP-1 is involved in the regulation of food intake [18] it can also be exendin4 is so involved. The anorectic effects of GLP-1 have been examined typically just over several hours and not for days. The relatively short-term decrease in food intake fits more with exendin-4 being a taste aversive agent, as suggested already [19], than with it being an anorectic agent. In our long-term study we weighed the animals once weekly and hence we missed the initial drop in food intake and body weight. Except for the bedding being obviously drier each morning in the treated diabetic animals, we could not detect any deleterious effects of exendin-4 on the animals. We therefore suggest that exendin4 might prove to be superior to GLP-1 as a treatment for Type II diabetes in humans.

Acknowledgements. D. Muller, Metabolic Section, NIA, helped us with statistics. Dr. D. Taub, Laboratory of Immunology, NIA, discussed the immunological issues with us. Dr. R. Andres, Laboratory of Clinical Investigation, encouraged us and edited the manuscript. Without the positive and on-going support of our Scientific Director, Dr. D.L. Longo, at the NIA, these studies would not have been done. 


\section{References}

1. Ghazzi MN, Perez JE, Antonucci TK et al. (1997) Cardiac and glycemic benefits of troglitazone treatment in NIDDM. Diabetes 46: 433-439

2. UK Prospective Study Group (1995) UK Prospective Diabetes Study 16: Overview of 6 years' therapy of Type II diabetes: a progressive disease. Diabetes 44: 1249-1258

3. Gutniak M, Orskov C, Holst JJ, Ahren B, Efendic S (1992) Antidiabetogenic effect of glucagon-like peptide-1 (7-36) amide in normal subjects and patients with diabetes mellitus. N Engl J Med 326: 1316-1322

4. Nauck MA, Kleine N, Orskov C, Holst JJ, Willms B, Creutzfeldt W (1993) Normalization of fasting hyperglycaemia by exogenous glucagon-like peptide 1 (7-36) amide in Type II (non-insulin-dependent) diabetic patients. Diabetologia 36: 741-744

5. Elahi D, McAloon-Dyke M, Fukagawa NK et al. (1994) The insulinotropic actions of glucose-dependent insulinotropic polypeptide (GIP) and glucagon-like peptide-1 (7-37) in normal and diabetic subjects. Regul Pept 51: 63-74

6. Willms B, Werner J, Holst JJ, Orskov C, Creutzfeldt W, Nauck MA (1996) Gastric emptying, glocose responses, and insulin secretion after a liquid test meal: effects of exogenous glucagon-like peptide-1-(7-36) amide in Type II (non-insulin-dependent) diabetic patients. J Clin Endocrinol Metab 81: 327-332

7. Nathan D, Scheiber E, Fogel H, Mosjov S, Habener JF (1992) Insulinotropic action of glucagonlike peptide-1(7-37) in diabetic and non-diabetic subjects. Diabetes Care 15: 270-276

8. De Ore K, Greig NH, Halloway HW, Wang Y, Perfetti R, Egan JM (1997) The effects of GLP-1 on insulin release in young and old rats in the fasting state and during an intravenous glucose tolerance test. J Gerontol B Psychol Sci Soc Sci 52:B245-B249

9. Ritzel R, Orskov C, Holst JJ, Nauck MA (1995) Pharmacokinetic, insulinotropic, and glucagonostatic properties of GLP-1 [7-36 amide] after subcutaneous injection in heal- thy volunteers. Dose-response-relationships. Diabetologia 38: 720-725

10. Chen YE, Drucker DJ (1997) Tissus-specific expression of unique mRNAs that encode pro-glucagon-derived peptides or exendin 4 in the lizard. J Biol Chem 272: 4108-4115

11. Goke R, Fehmann H-C, Linn T et al. (1993) Exendin-4 is a potent agonist and truncated exendin-(9-39)-amide an antagonist at the GLP-1-(7-36)-amide receptor of insulin-secreting $\beta$-cells. J Biol Chem 268: 19650-19655

12. Thorens B, Porret A, Buhler L, Deng SP, Morel P, Widman C (1993) Cloning and functional expression of the GLP-1 receptor: Demonstration that exendin- 4 is an agonist and exendin-3 (9-39) is an antagonist of the receptor. Diabetes 42: $1678-1672$

13. Wang Y, Perfetti R, Greig NH et al. (1997) Glucagon-like peptide-1 can reverse the age-related decline in glucose tolerance in rats. J Clin Invest 99: 2883-2889

14. Perfetti R, Montrose-Rafizadeh C, Liotta AS, Egan JM (1995) Age-dependent reduction in insulin secretion and insulin mRNA in isolated islets from rats. Am J Physiol 269:E983-E990

15. Montrose-Rafizadeh C, Wang Y, Janczewski AM, Henderson TE, Egan JM (1997) Overexpression of glucagon-like peptide-1 receptor in an insulin-secreting cell line enhances glucose responsiveness. Mol Cell Endocrinol 130: 109-117

16. Kolligs F, Fehmann H-C, Goke R, Goke B (1995) Reduction of the the incretin effect in rats by the glucagon-like peptide 1 receptor antagonist exendin (9-39) amide. Diabetes 44: 16-19

17. Bhavsar S, Lachappell R, Watkins J, Young A (1998) Comparison of glucose lowering effects of exendin-4 and GLP-1 in diabetic db/db mice. Diabetes 47 [Suppl 1]:A192 (Abstract)

18. Flint A, Raben A, Astrup A, Holst JJ (1998) Glucagon-like peptide 1 promotes satiety and suppresses energy intake in humans. J Clin Invest 101: 515-520

19. Thiele TE, Van Dijk G, Campfield A (1997) Central infusion of GLP-1, but not leptin, produces conditioned taste aversions in rats. Am J Physiol 272:R725-R730 